https://doi.org/10.24101/logos.2018.33

Gauta 20180412

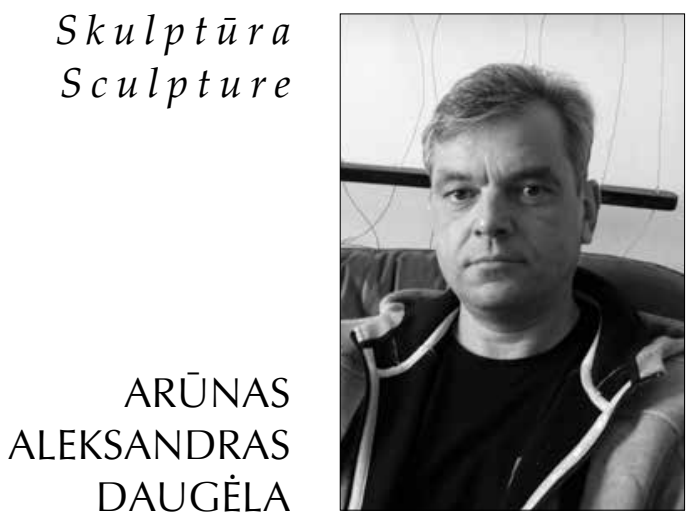

\title{
DAILININKAS ARŪNAS ALEKSANDRAS DAUGĖLA
}

Menininkas Arūnas Aleksandras DAUGĖLA gimė 1963 m. Kaune. Mokėsi vaikų dailès mokykloje. 19801986 m., pasirinkęs stiklininko specialybę, studijavo Vilniaus dailės instituto (dabar VDA) Kauno taikomosios dailès fakultete. Baigęs studijas gavo paskyrimą i Kauno „Aleksoto“ stiklo fabriką. Šiame fabrike dailininku-dizaineriu A. A. Daugèla dirbo 1986-1994 m.: projektavo įvairios paskirties serijinius bei mažo tiražo stiklo objektus. Stiklo pramonejje sukaupta Daugèlos patirtis nebuvo vienintelè - pastarąji dešimtmetị dailininkas kurį laiką bendradarbiavo su privačia stiklo studija "Stiklo paslaptis", įsikūrusia Kaune. Tačiau pagrindinis Daugèlos darbas jau beveik tris dešimtmečius trunkanti pedagoginè veikla. 1990 m. menininkas pradèjo dėstyti Vilniaus dailès akademijos Kauno fakulteto Stiklo katedroje, kur iki šiol eina docento pareigas, dèsto įvairias stiklo specialybès disciplinas, vadovauja baigiamiesiems bakalauriniams ir magistriniams darbams. Taip pat dailininkas kuria autorinius kūrinius, nuolat dalyvauja parodose.

\section{Artist Arūnas Aleksandras Daugèla}

Arūnas Aleksandras Daugèla was born in 1963 in Kaunas. In tender age he studied at children's art school. From 1980 to 1986, he studied glass art in Kaunas Applied Arts faculty of Vilnius Art Institute (now Vilnius Academy of Arts). After graduation, he was employed at Kaunas „Aleksotas“ manufactory. Here Daugèla worked as a designer from 1986 to 1994, creating various items of mass production and limited edition glass objects. During that period he also cooperated with "Glass Magic" studio. For the last 30 years, the main occupation of Daugèla is pedagogical work. In 1990, the artist started lecturing in the Glass Art Department of Kaunas Faculty of Vilnius Academy of Arts. Now he lectures on various glass art subjects in bachelor and master degree courses. The artist also produces some artworks and participates in exhibitions.

Raimonda Simanaitienè Vytauto Didžiojo universitetas Vytautas Magnus University

RAKTAŽODŽIAI: Arūnas Aleksandras Daugèla, stiklas, dailininkas.

KEY WORDS: Arūnas Aleksandras Daugèla, glass, artist. 


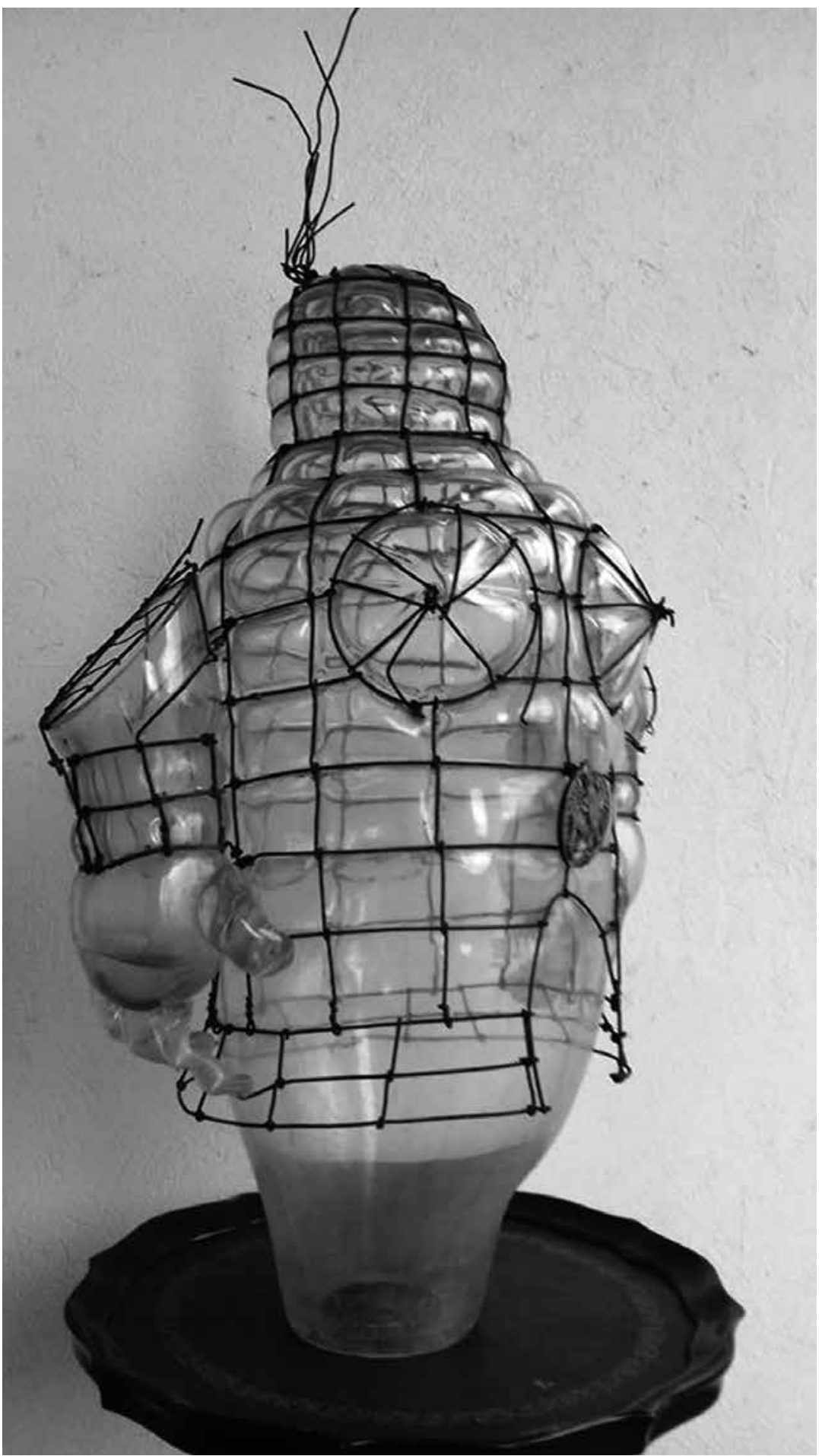

A. A. DAUGE்LA. Riteris. 1991 


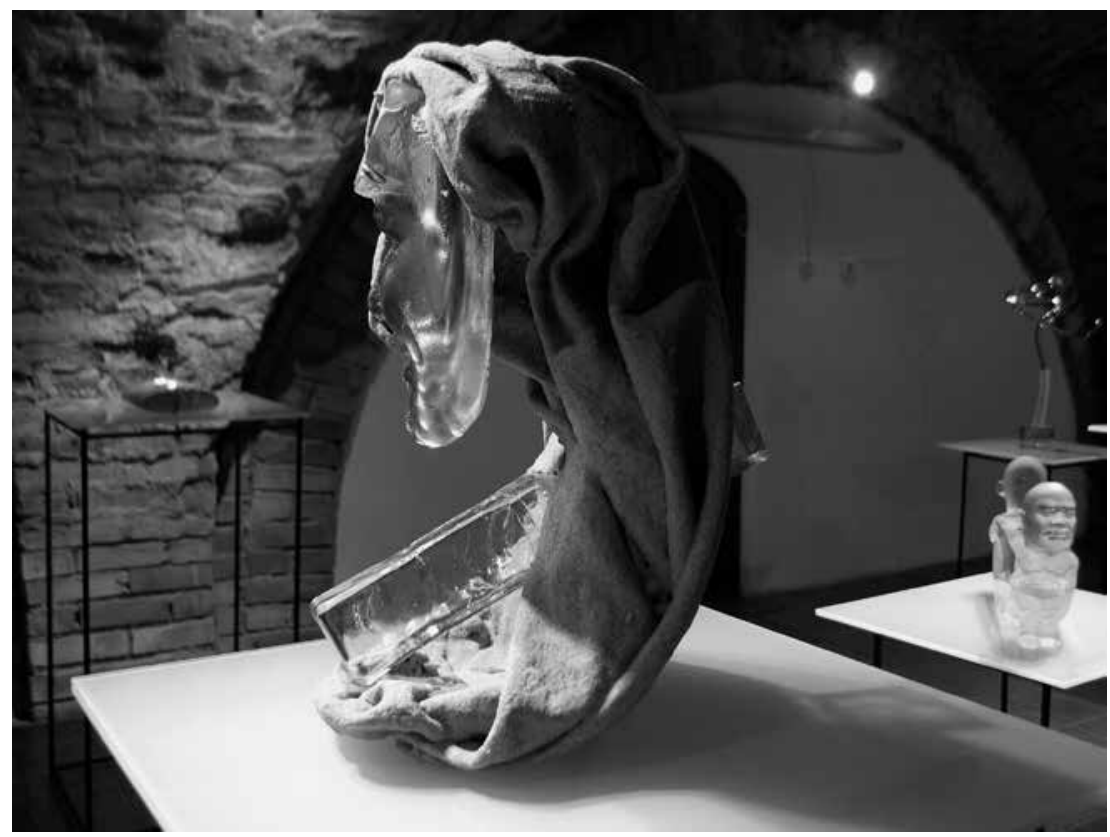

A. A. DAUGĖLA. Lošéjas. Iš serijos Smèlio žmonès. 2005

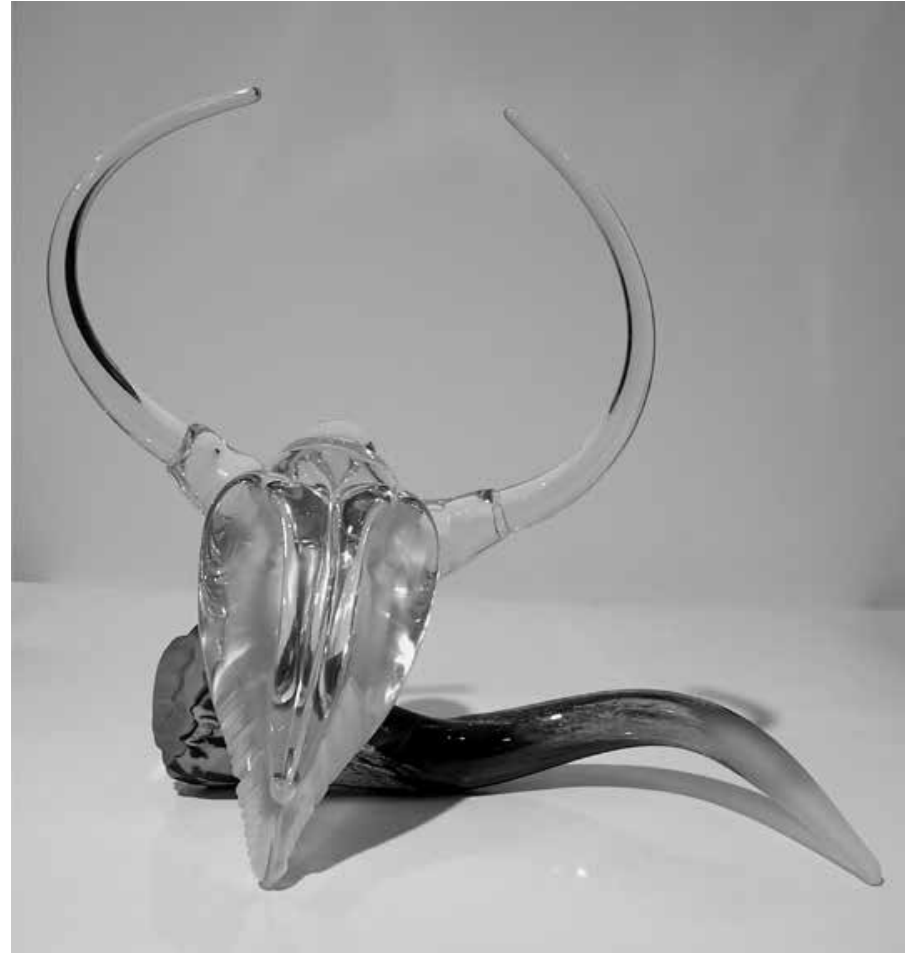

A. A. DAUGÉLA. Trofëjus. 2010 


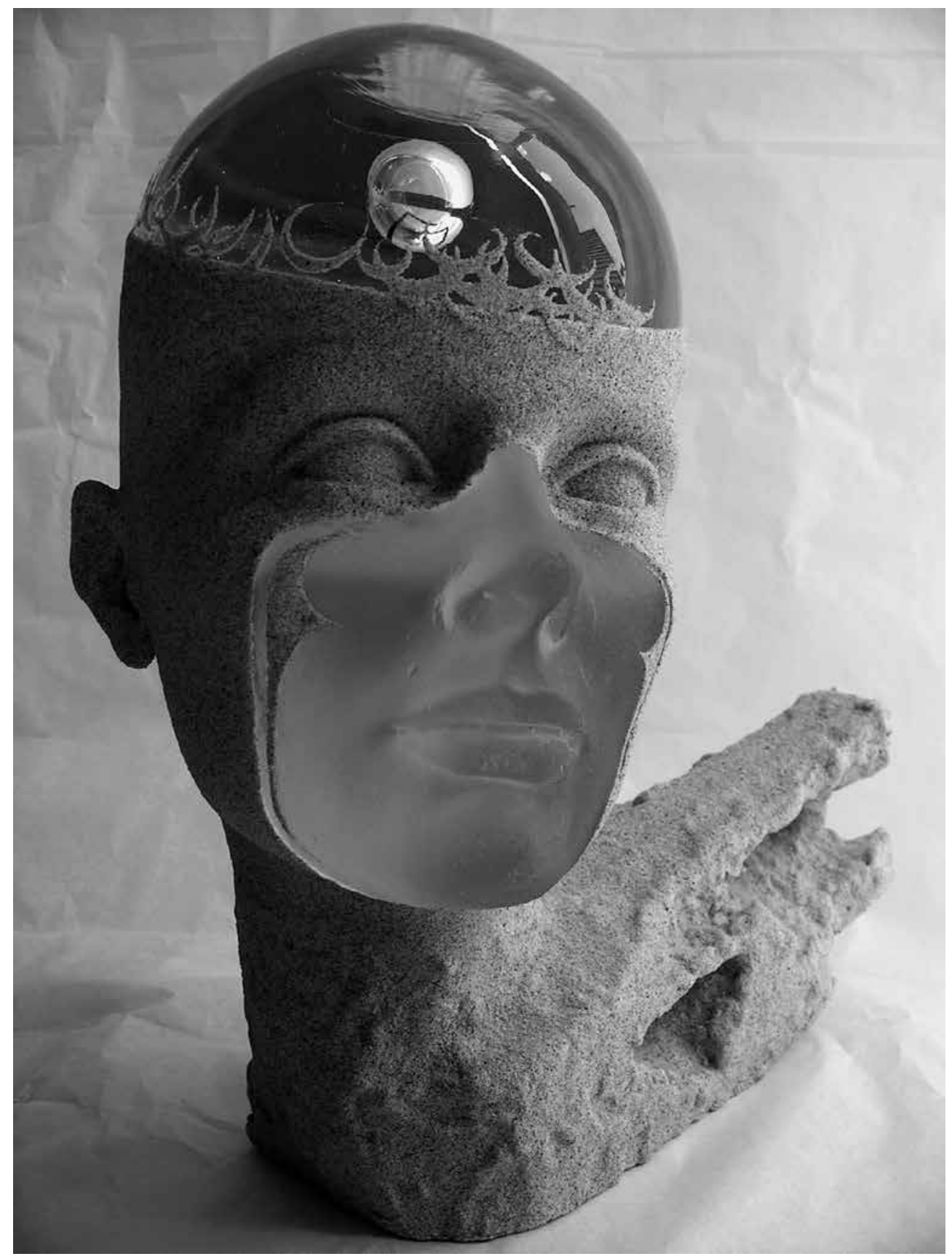

A. A. DAUGĖLA. Mergaitė. Iš serijos Smèlio žmonès. 2005 


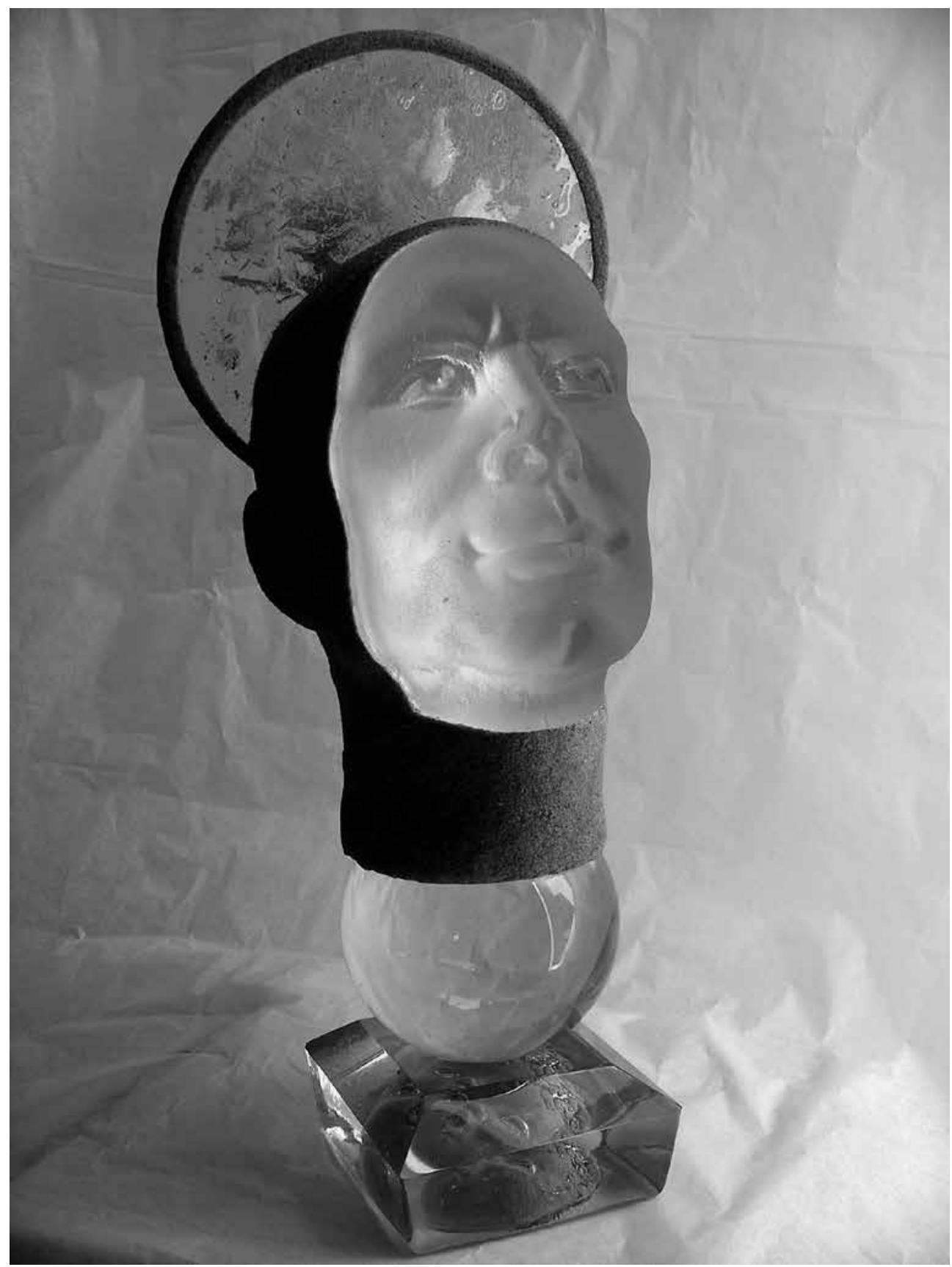

A. A. DAUGĖLA. Žiūrintis i dangų. 2005 


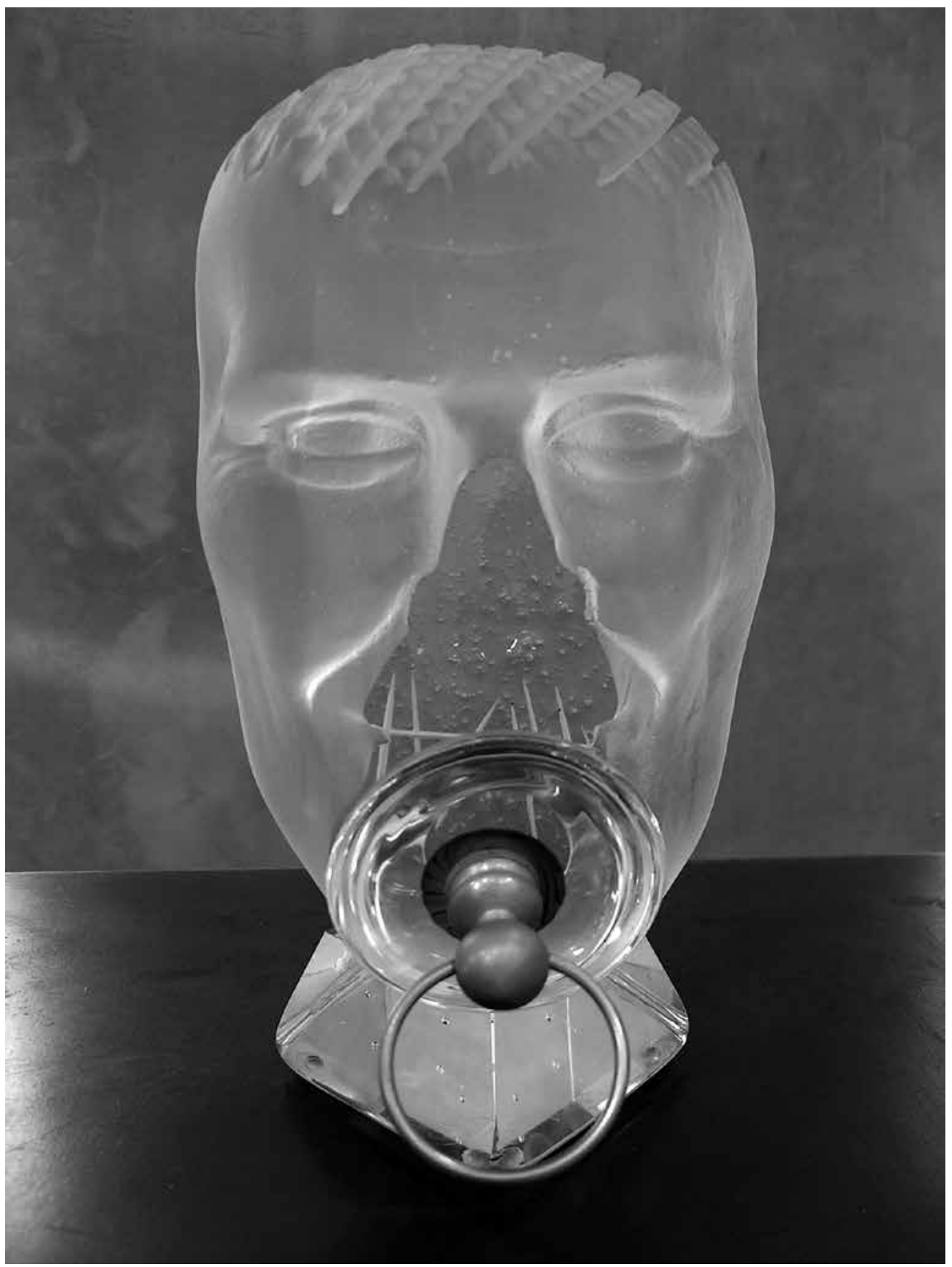

A. A. DAUGÉLA. Ramybè. 2005 


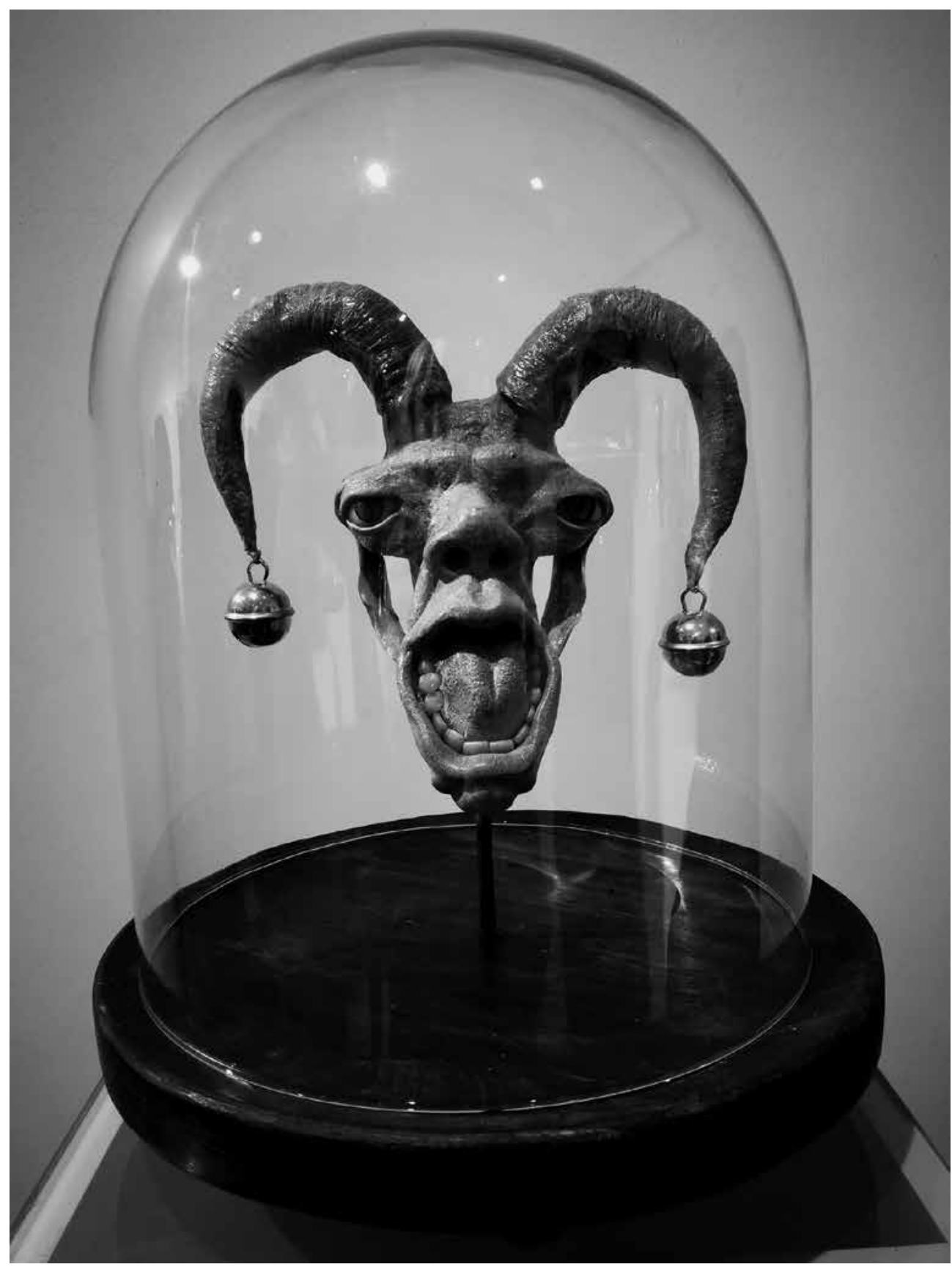

A. A. DAUGÉLA. Miško pasaka. Antras draugas. 2017 


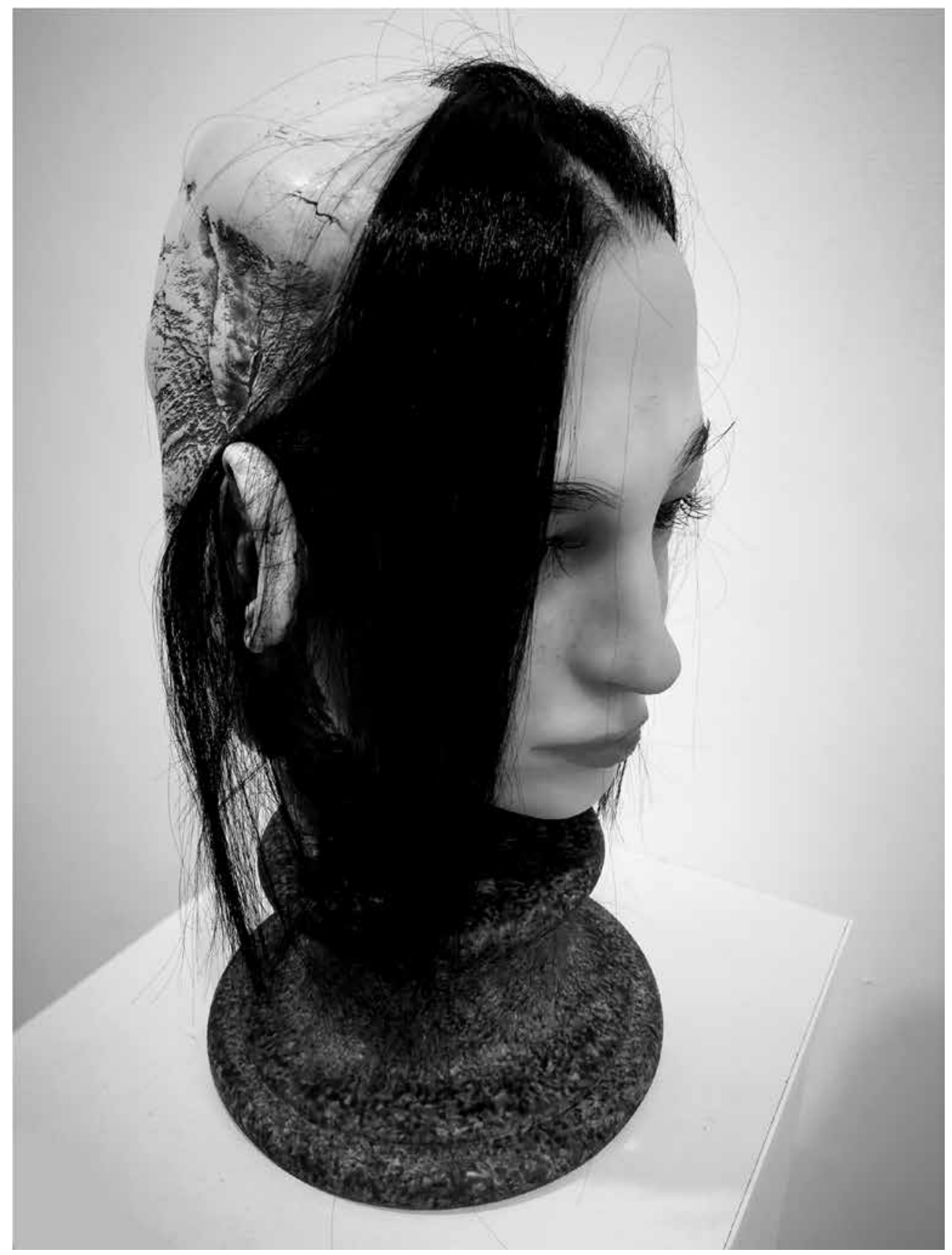

A. A. DAUGE்LA. Jana. 2018 